\title{
Railroad Ballast Particle Breakage with Unique Laboratory Test Method
}

\author{
E. Juhász ${ }^{1}$, Sz. Fischer ${ }^{1}$ \\ ${ }^{1}$ Department of Transport Infrastructure and Water Resources, Faculty of \\ Architecture, Civil Engineering and Transport Sciences, Széchenyi István \\ University \\ Egyetem tér 1., H-9026 Győr, Hungary \\ e-mail: juhasz.erika@sze.hu, fischersz@sze.hu
}

Abstract: This paper demonstrates the results in the research topic of the railway ballast particles' breakage test with unique laboratory test. The most railway lines in the world have so called traditional superstructure (ballasted tracks). In the past few years there were a lot of railway rehabilitation projects in Hungary, as well as abroad. Nowadays cannot be expected that there is enough quantity of railway ballast in adequate quality, because of the modifications and restrictions in the related regulations in Hungary since 2010. In Hungary there are only a few quarries which are able to ensure adequate railway ballast material for construction and maintenance projects for speed values between 120 and $160 \mathrm{~km} / \mathrm{h}$. This may cause supply and quality risk in production of railway ballast. The authors' research's main goal is to be able to simulate the stress-strain effect of ballast particles in real and objective way in laboratory conditions as well as in discrete element modelling.

Keywords: ballast, breakage, laboratory test, railway, degradation

\section{Introduction}

An article was published [1] in 2015 with results of an R\&D on individual breakage test method in laboratory related to railway ballast. Since that several other publication was published in this topic [2-6]. The authors would like to supplement that documents with actual, up-to date outcomes.

The rock physical suitability of railway ballast materials is determined by laboratory tests in in the EU, formulated in the same product standard. 
There are two types of standardized tests in the aspect of rock physic characteristics of railway ballast:

- Micro-Deval abrasion test according to MSZ EN 1097-1:2012 [7],

- Los Angeles abrasion test in accordance with MSZ EN 1097-2:2010 [8].

These are determined in the MSZ EN 13450:2003 product standard [9].

These two test types are absolutely suitable for satisfy defining the abrasion characteristics of a given aggregate sample and for ensuring the production stability in the quarries and these are indispensable to guarantee the required quality and to ensure the checking of the quality level in case of ready constructed railway tracks. However, it's not suitable for modelling the railway loads (i.e. loads from vehicles and other effects) in a real way.

The authors worked out an individual laboratory test method [1, 3], because other test methods can't consider the abrasion and breakage (real particle degradation) due to dynamic force and vibration.

The results of the unique laboratory tests with the required limits in standards are compared with the related regulation of MÁV (Hungarian Railways) [10]. Required time intervals of ballast screening are able to be calculated according to laboratory test results.

It is known that No. MÁV 102345/1995. PHMSZ in accordance with the decree [10], the "Constructions for superstructure facilities and quality standards for bedding instruction" has been tightened on the basis of the $4^{\text {th }}$ amendement [10], which came into force in January 2010. According to the $3^{\text {rd }}$ amendement of 2008, there was a (positive) tolerance range for the Los Angeles breakdown and the MicroDeval wear, which was deleted in $4^{\text {th }}$ amendement. The values for the speed categories are also partially have changed, usually tightened (see Table 1. and Table 2.). 
E. Juhász and Sz. Fischer. - Acta Technica Jaurinensis, Vol. 12, No. 1, pp. 26-54, 2019

Table 1. Requirements to $L A_{R B}$ values [10]

\begin{tabular}{|c|c|c|c|c|}
\hline \multirow{3}{*}{$\begin{array}{c}\text { strength } \\
\text { requirement } \\
\text { allowed speed } \\
(\mathrm{km} / \mathrm{h})\end{array}$} & \multicolumn{4}{|c|}{$\mathbf{L A}_{\mathbf{R B}}$} \\
\hline & \multicolumn{2}{|c|}{2008 - 2009} & \multicolumn{2}{|c|}{ from 2010} \\
\hline & requirement & $\begin{array}{c}\text { allowed } \\
\text { difference }\end{array}$ & requirement & $\begin{array}{c}\text { allowed } \\
\text { difference }\end{array}$ \\
\hline$V>160$ & 16 & $\begin{array}{c}+2 \\
\text { (negative is } \\
\text { not limited) }\end{array}$ & 16 & - \\
\hline $160 \geq V>120$ & 16 & $\begin{array}{c}+4 \\
\text { (negative is } \\
\text { not limited) }\end{array}$ & 16 & - \\
\hline $120 \geq V \geq 80$ & 16 & $\begin{array}{c}+4 \\
\text { (negative is } \\
\text { not limited) }\end{array}$ & 16 & - \\
\hline $80>V \geq 40$ & 24 & $\begin{array}{c}+4 \\
\text { (negative is } \\
\text { not limited) }\end{array}$ & 20 & - \\
\hline $\mathrm{V}<40$ & 24 & $\begin{array}{c}+4 \\
\text { (negative is } \\
\text { not limited) }\end{array}$ & 24 & - \\
\hline
\end{tabular}

Table 2. Requirements to $M_{D E} R B$ values [10]

\begin{tabular}{|c|c|c|c|c|}
\hline \multirow{3}{*}{$\begin{array}{c}\text { strength } \\
\text { requirement } \\
\text { allowed speed } \\
(\mathrm{km} / \mathrm{h})\end{array}$} & \multicolumn{4}{|c|}{ MDERB } \\
\hline & \multicolumn{2}{|c|}{$2008-2009$} & \multicolumn{2}{|c|}{ from 2010} \\
\hline & requirement & $\begin{array}{c}\text { allowed } \\
\text { difference }\end{array}$ & requirement & $\begin{array}{c}\text { allowed } \\
\text { difference }\end{array}$ \\
\hline$V>160$ & 11 & $\begin{array}{c}+2 \\
\text { (negative is } \\
\text { not limited) }\end{array}$ & 11 & - \\
\hline $160 \geq V>120$ & 11 & $\begin{array}{c}+4 \\
\text { (negative is } \\
\text { not limited) }\end{array}$ & 11 & - \\
\hline $120 \geq V \geq 80$ & 11 & $\begin{array}{c}+4 \\
\text { (negative is } \\
\text { not limited) }\end{array}$ & 15 & - \\
\hline $80>V \geq 40$ & 15 & $\begin{array}{c}+4 \\
\text { (negative is } \\
\text { not limited) }\end{array}$ & 15 & - \\
\hline $\mathrm{V}<40$ & 15 & $\begin{array}{c}+4 \\
\text { (negative is } \\
\text { not limited) }\end{array}$ & 15 & - \\
\hline
\end{tabular}




\section{History of the research}

The research topic has prestigious international literature and sources. Foreign researchers dealt with different areas and they worked out different methods as follows:

- laboratory tests $[11,12,13,14,15,16,17,18,19]$

- finite element modelling (FEM) [13],

- discrete element modelling (DEM) and/or 3D particle generation [19, 20],

- in-situ tests in railway tracks [21].

The researchers worked out several special parameters, constants and indexes that helped the progression of the research (e.g. Marshal, Hardin, Lee and Farhoomand breakages, $\mathrm{BBI}$ index, $\mathrm{B}_{\mathrm{R}}$ index, etc.).

An international literature review was carried out by the authors and from the results the following main themes and methods were taken into consideration:

- searching of relationship between cohesion as well as inner friction anger, railway ballast aggregate abrasion, water permeability of material and its layer [16];

- definition of relationship between Particle Size Distribution (PSD) and particle degradation phenomenon of ballast aggregate, as well as definition of better PSD for real loadings [15, 16];

- research of 'angularity breakage' phenomena [18];

- DEM models were validated and DEM generations method of much more realistic particle shapes was investigated [22];

- measurement of railway ballast's breakage, implementation of laboratory and field tests with and without geosynthetic inclusions [13, 14, 15, 21];

- research of ballast particle breakage due to tie tamping [11, 12];

- investigation of ballast with glued technique [17].

The authors collected several significant results at the international literature review which can be read in the previous publication [4]. 


\section{The laboratory test's procedure and parameters}

The base of the procedure is a special laboratory dynamic actuator The laboratory test method was developed as a part of an R\&D financed by Colas Északkö Ltd. and a report more publications - that were written in this topic $[1,2,3,4,5,6]$.

In 2017 and 2018 the testing and evaluating method was accomplished by specify more precise deterioration process, considering only determined particle fraction, etc. The authors used the following parameters during measurements and evaluation:

- two different types of railway ballast samples from andesite material and from different quarries

- the specimens are in accordance with MSZ EN 13450:2003 [9], A type, $31,5 / 50 \mathrm{~mm}$, the authors received from Colas Északkő Ltd.

- the specimens have the following stone physic parameters (laboratory test were done by accredited laboratory of Colas Északkő Ltd.):

- sample No. 1: $\mathrm{LA}_{\mathrm{RB}}=19 \%, \mathrm{M}_{\mathrm{DE}} \mathrm{RB}=17 \%$;

○ sample No. 2 : $\mathrm{LA}_{\mathrm{RB}}=16 \%, \mathrm{M}_{\mathrm{DE}} \mathrm{RB}=4 \%$;

- dynamic tests with pulsator in different cycles (i.e. until 0.1, 0.2, 0.5, 1.0, $1.5,3.0$ and 5.0 million cycles), in every test with only fresh ballast material with particle fraction $d \geq 22.4 \mathrm{~mm}$ (before pulsating $d<22.4 \mathrm{~mm}$ particles were screened out and they were not put back), where $d$ is the size of the particle; in the 2014 series of measurements, the particle sizes below $22.4 \mathrm{~mm}$ were left in the tests, this was the reason why it is not possible to compare the current measurement results with the old ones;

- determination of PSD curves with screening related to sub-samples Before Pulsating (BP) test;

- determination of PSD curves with screening related to sub-samples After Pulsating (AP) test.

\subsection{Presentation of the individual fatigue laboratory test}

The individual laboratory testing method is a dynamic pulsating test for that the six lower frames of a 10-level steel shear box were used [1]. Frames were fixes together with steel metric screws. They prevent the horizontal relative displacements. The shear box including some steel rolls which were not fixed to the down side of the bottom frame.

The built-up layer structure is the following (see Table 3). 


\section{Table 3. The built-up layer structure}

steel loading plate

$\mathrm{D}=300 \mathrm{~mm}$ steel plate with circular shape $(\mathrm{D}=$ diameter $)$

$0.46 \times 0.42 \mathrm{~m}$

\begin{tabular}{|c|c|c|c|c|}
\hline $\begin{array}{c}\text { 30-cm-thick- } \\
\text { layer } \\
\text { wooden } \\
\text { sleepers } \\
\text { around the } \\
\text { crushed stone } \\
\text { samples }\end{array}$ & 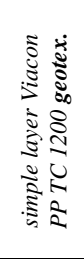 & $\begin{array}{l}\text { 30-cm-thick-layer } \\
\text { crushed stone } \\
\text { cross section } 0.46 \times 0.46 \mathrm{~m}\end{array}$ & 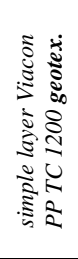 & $\begin{array}{c}\text { 30-cm-thick- } \\
\text { layer } \\
\text { wooden } \\
\text { sleepers } \\
\text { around the } \\
\text { crushed stone } \\
\text { samples }\end{array}$ \\
\hline \multicolumn{5}{|c|}{$\begin{array}{c}\text { simple layer } \\
\text { heat treated, non-woven, high strength geotextile with } 1200 \mathrm{~g} / \mathbf{m}^{2} \text { mass } \\
\text { type: Viacon GEO PP TC } 1200 \\
\text { on the whole } 1.0 \times 1.0 \mathrm{~m} \text { area }\end{array}$} \\
\hline \multicolumn{5}{|c|}{$\begin{array}{l}\text { 10-cm-thick-layer } \\
\text { Sand } \\
\text { type: } \mathrm{E}_{2}, 20.42 \mathrm{MPa} \text { according to MSZ 2509-3:1989 [23] } \\
\text { on the whole } 1.0 \times 1.0 \mathrm{~m} \text { area }\end{array}$} \\
\hline \multicolumn{5}{|c|}{$\begin{array}{l}\text { simple layer } \\
\mathbf{1 5 0} \mathbf{g} / \mathbf{m}^{\mathbf{2}} \text { mass geotextilie } \\
\text { type: Naue Secutex } 151 \mathrm{GRK} \\
\text { on the whole } 1.0 \times 1.0 \mathrm{~m} \text { area } \\
\end{array}$} \\
\hline & & $\begin{array}{l}\text { 20-cm-thick layer } \\
\text { eXtruded Polystirol (XPS } \\
\text { type: Austrotherm Thermoplan } \\
\text { sheets on the whole } 1.0 \times 1.0 \mathrm{~m} \text { are }\end{array}$ & & \\
\hline
\end{tabular}

The samples (railway ballast) were put in the middle of the shear box into the $0.46 \times 0.46 \mathrm{~m}$ area and $0.30 \mathrm{~m}$ high space where wooden sleepers are around. The structure can be seen in Table 1. Reducing and excluding wall effect the inner sides of wooden sleepers were covered with $1200 \mathrm{~g} / \mathrm{m}^{2}$ mass geotextile layers (where stone and wooden sleepers would interact). A loading plate from steel (size: $46 \times 42 \mathrm{~cm}$ and $\mathrm{D}=300 \mathrm{~mm}$ circular steel plate) were put onto ballast samples to be able to achieve uniform load distribution.

The assembly without loading plates can be seen in Figures 1-5. 
E. Juhász and Sz. Fischer. - Acta Technica Jaurinensis, Vol. 12, No. 1, pp. 26-54, 2019

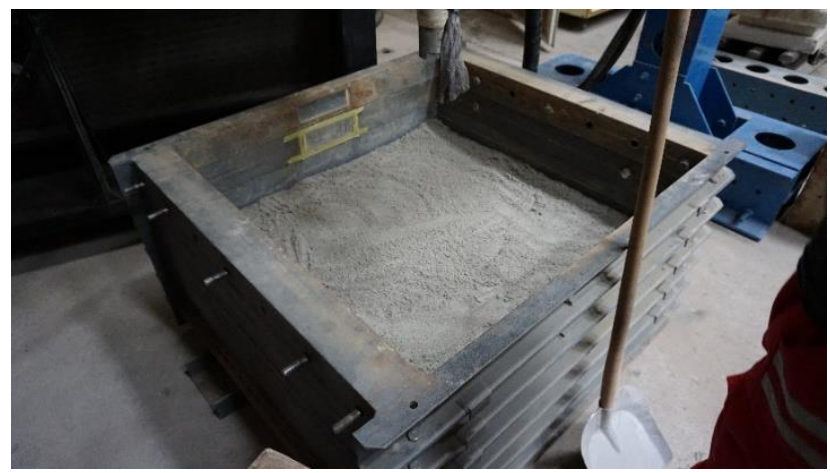

Figure 1. The 10-cm-thick-layer sand on the XPS layer

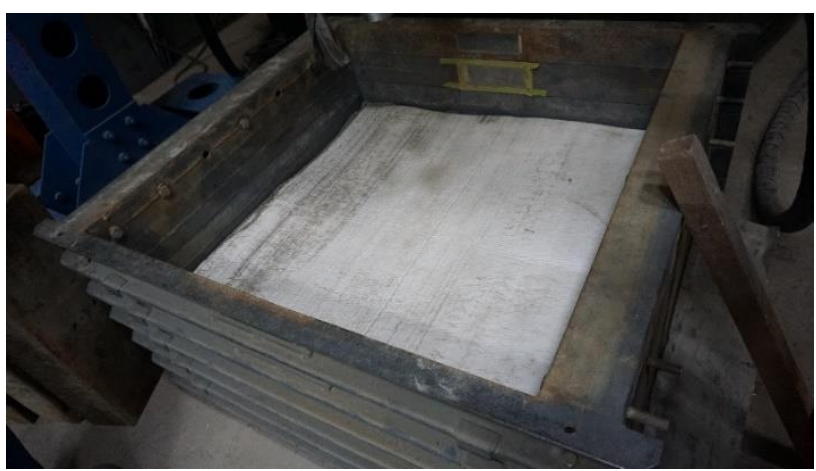

Figure 2. The high strength geotextilie on the sand layer

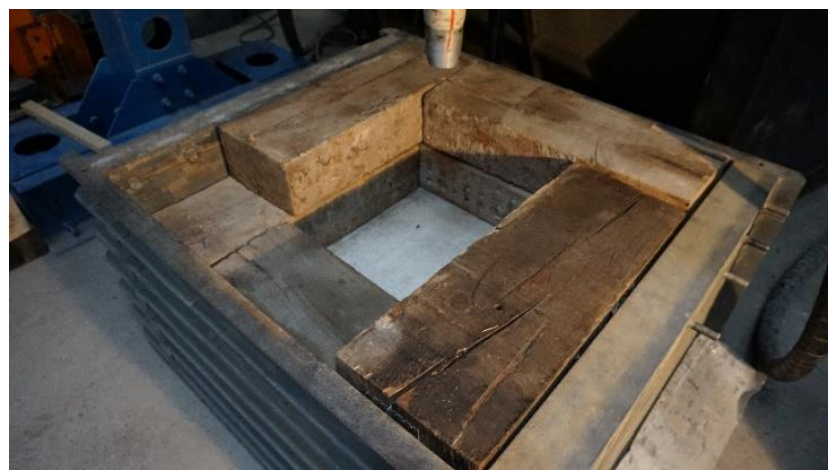

Figure 3. The wooden sleepers in the shear box 


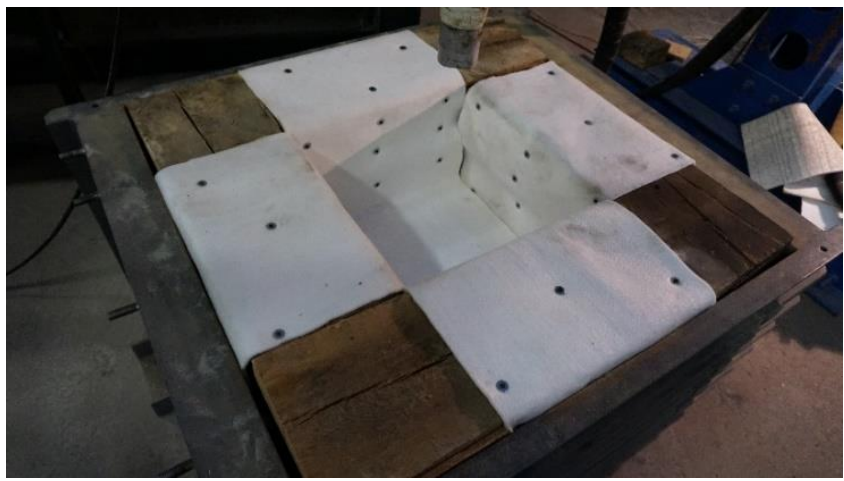

Figure 4. The geotextilie among the wooden sleepers

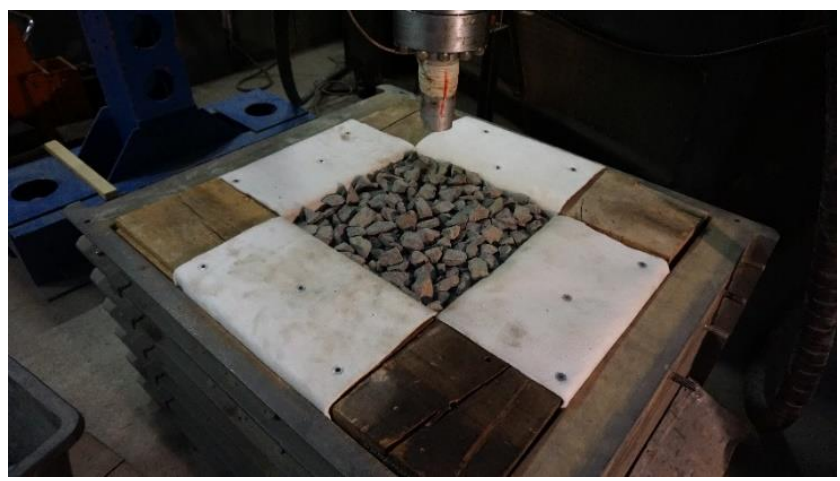

Figure 5. The sample of ballast material in place

Laboratory measurements were executed with dynamic actuator in previously defined loading cycles. Laboratory test parameters (frequency, load values, etc.) were published in $[1,3]$ papers in detailed formats, they are not written here due to limited space. After pulsating tests PSD (particle size distribution) data sets were determined (measured) beside them several parameters (see below) were calculated $[1,2,3]$ :

- $\quad F_{V}(\%)($ see eqs. $(1-5))$;

- $\quad B B I$ (see eq. (6));

- $\quad B_{R},\left(B_{R}\right.$ is a parameter is similar to BBI, but it considers different areas in PSD [24]);

- $\quad d<22.4 \mathrm{~mm}$ in mass percentage; 
- $d<0.5 \mathrm{~mm}$ in mass percentage;

- $\quad d<0.063 \mathrm{~mm}$ in mass percentage;

- $\quad d_{60} / d_{10}$ ratio (where $d_{60}$ is the particle size related to $60 \%$ in PSD curve, $d_{10}$ is the particle size related to $10 \%$ in PSD curve, and $d_{60} / d_{10}$ ratio means the ratio of $\left(d_{60} / d_{10}\right)_{A P} /\left(d_{60} / d_{10}\right)_{B P}$;

- $C_{C}$ ratio (where $C_{C}=d_{30}{ }^{2} /\left(d_{60} \times d_{10}\right), d_{30}$ is the particle size related to $30 \%$ in PSD curve, and $C_{C}$ ratio means the ratio of $\left(C_{C}\right)_{A P} /\left(C_{C}\right)_{B P}$;

- $M$ ratio (where $M$ is a special shape factor of PSD curve of railway ballast [25], and $M$ ratio means the ratio of $M_{A P} / M_{B P}$;

- $\lambda$ ratio (where $\lambda$ is a special shape factor of PSD curve of railway ballast that considers standard ballast PSD, as well [25], and $\lambda$ ratio means the ratio of $\left.\lambda_{A P} / \lambda_{B P}\right)$.

Calculations of $\mathrm{F}_{\mathrm{V}}$ and $\mathrm{BBI}$ parameters have to be explained, eqs. (1-6) give the meaning of these parameters $[1,2,3,14,15,26]$.

$$
\begin{gathered}
F_{V}=0.4 \cdot F_{19}+0.3 \cdot F_{6.7}+0.2 \cdot F_{1.18}+0.4 \cdot F_{0.15}, \\
F_{19}=\frac{D_{19}}{100} \cdot 27, \\
F_{6.7}=\frac{D_{6.7}}{100} \cdot 18, \\
F_{1.18}=\frac{D_{1.18}}{100} \cdot 11.5, \\
F_{0.15}=\frac{D_{0.15}}{100} \cdot 5.5,
\end{gathered}
$$

where " $\mathrm{D}$ " is the fallen mass percentage through the given diameter sieve.

$$
\mathrm{BBI}=\frac{A}{A+B},
$$

where $A$ is the area between the initial and final PSD curves [14, 15], B is the area between the arbitrary boundary of maximum breakage line and final PSD curve [14, $15]$.

The authors computed the required time intervals of ballast screening with the help of deterioration process obtained from parameters above. The prescribed values from standards were also computed. 


\section{Recent results}

The two ballast samples tested until 5-5 million cycles with dynamic pulsating laboratory test in more phases. The authors calculated the necessary parameters from PSD data sets are plotted in diagrams as a function of pulsating cycles in Figure 625 .

Following diagrams show the parameters in the consideration of the maximum 5-5 million loading cycles, as well as the results in Figure 6-25.

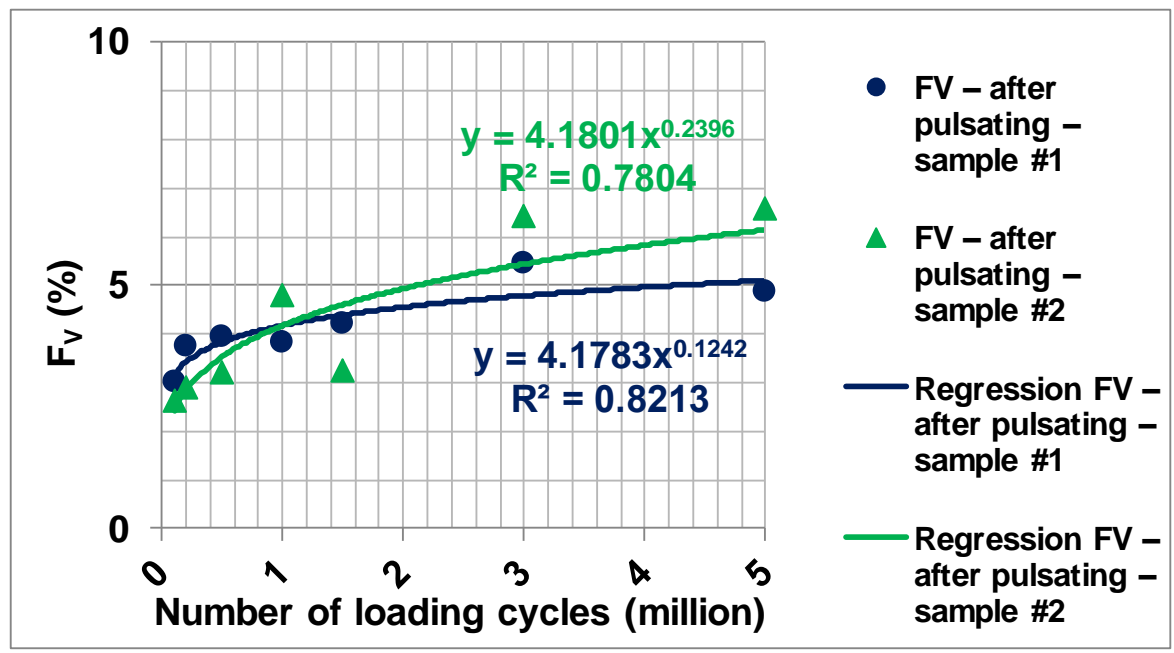

Figure 6. Results of the individual laboratory test $-F_{V}(\%)$ as a function of number of loading cycles; with power regression functions 
E. Juhász and Sz. Fischer. - Acta Technica Jaurinensis, Vol. 12, No. 1, pp. 26-54, 2019

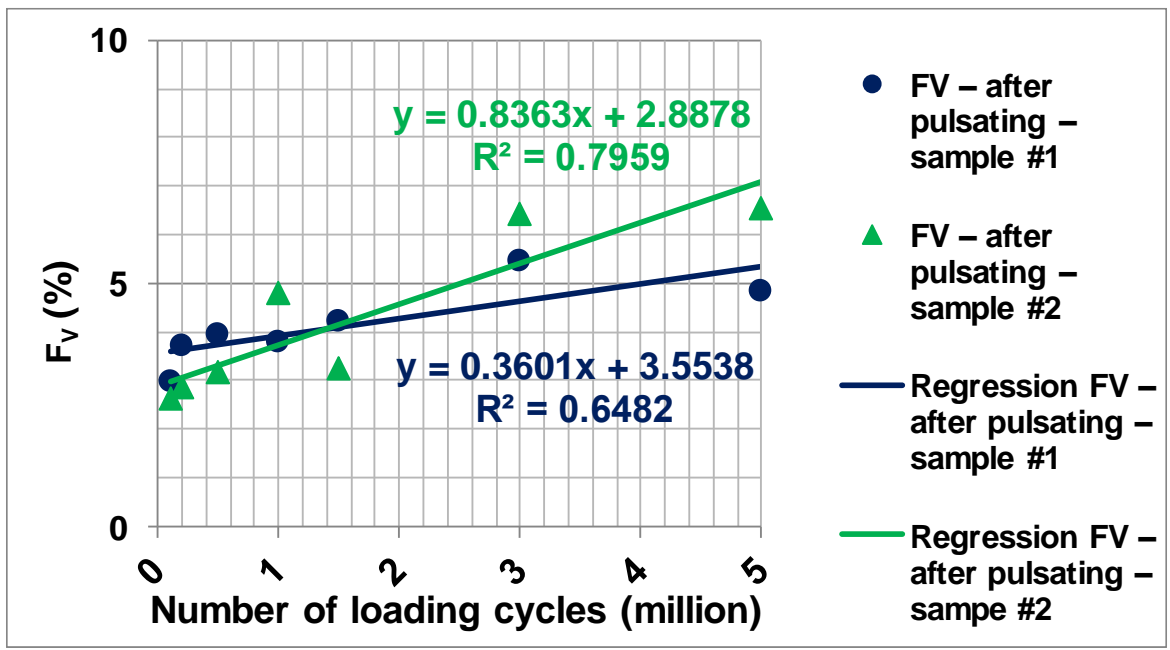

Figure 7. Results of the individual laboratory test $-F_{V}(\%)$ as a function of number of loading cycles; with linear regression functions

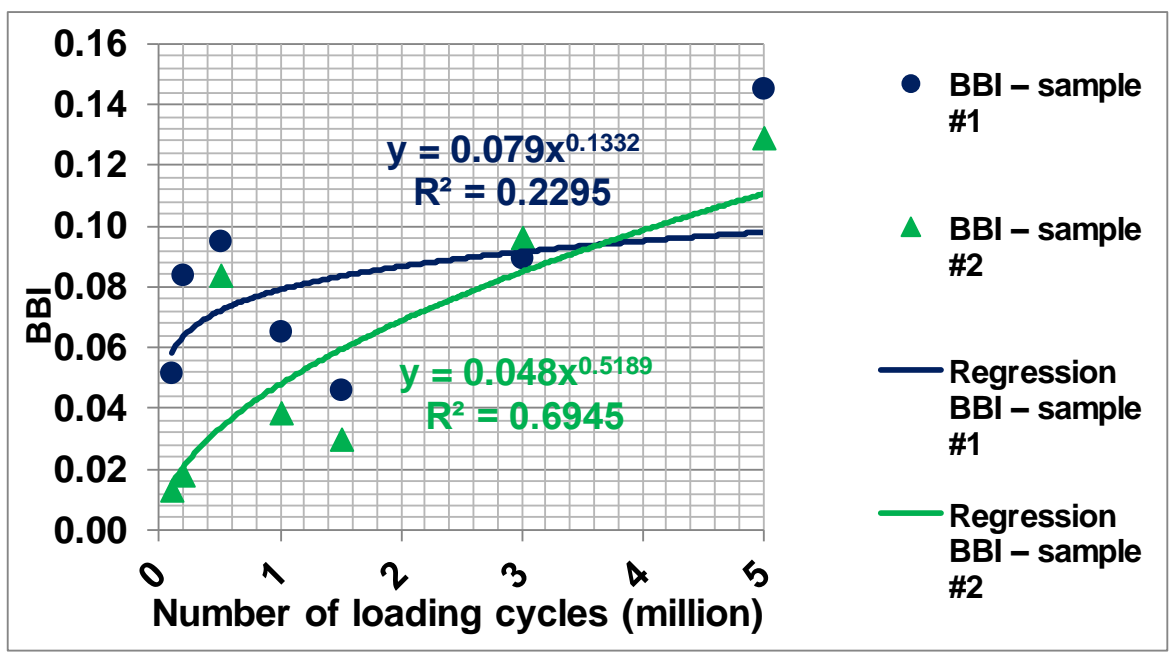

Figure 8. Results of the individual laboratory test-BBI as a function of number of loading cycles; with power regression functions 


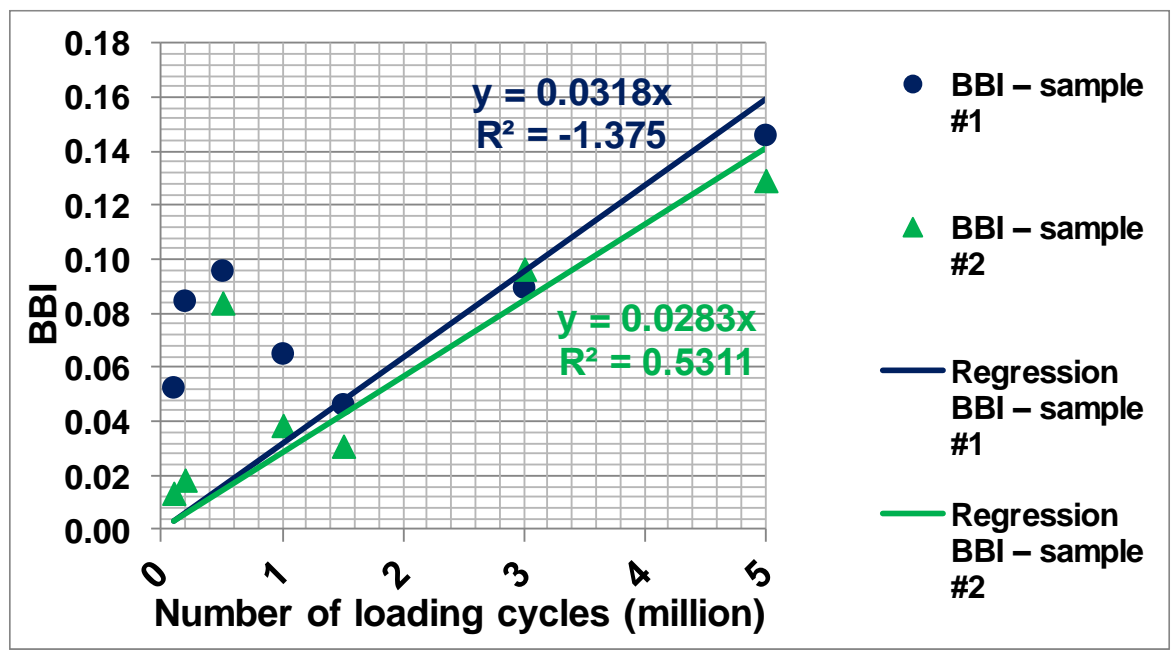

Figure 9. Results of the individual laboratory test-BBI as a function of number of loading cycles; with linear regression functions

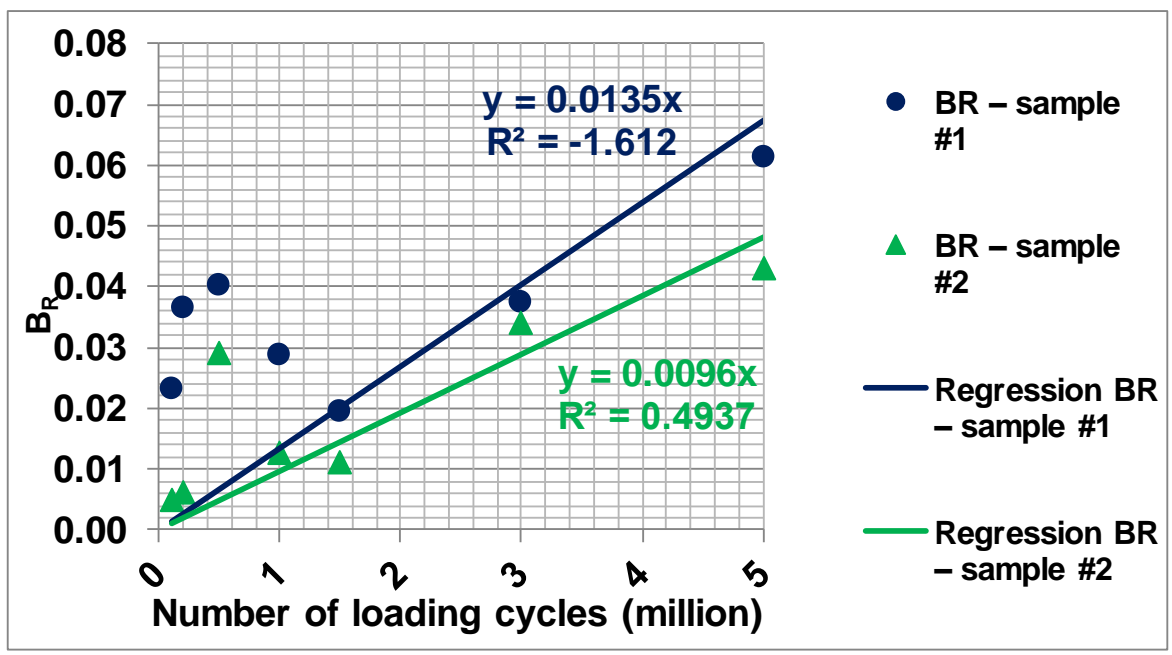

Figure 10. Results of the individual laboratory test $-B_{R}$ as a function of number of loading cycles; with power regression functions 


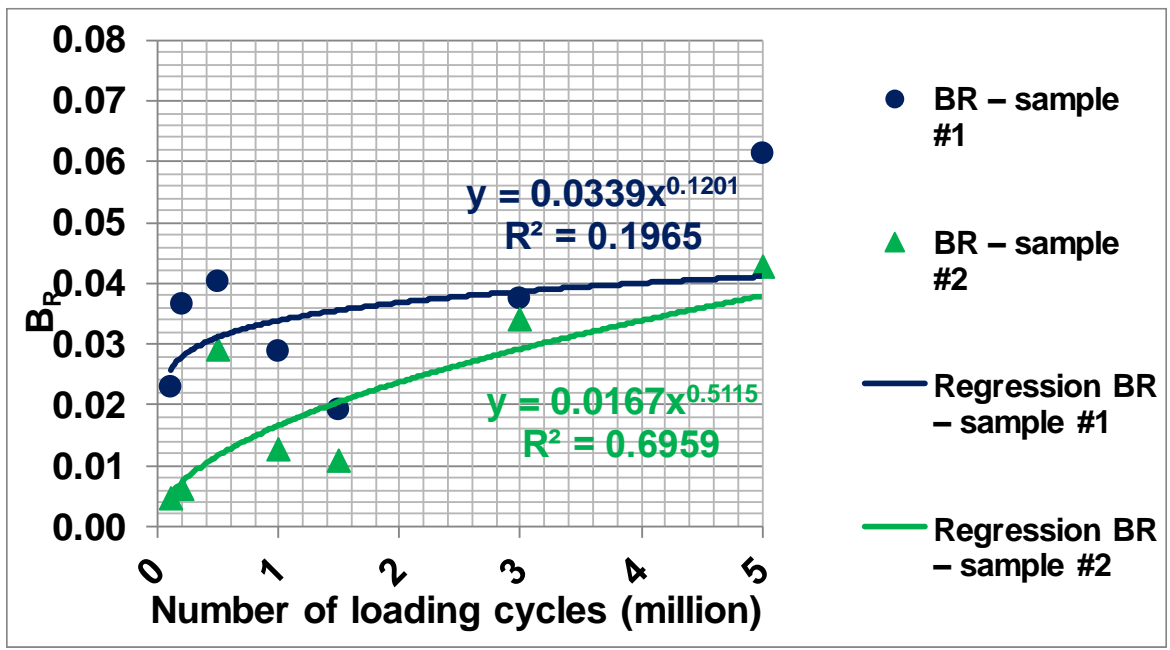

Figure 11. Results of the individual laboratory test $-B_{R}$ as a function of number of loading cycles; with linear regression functions

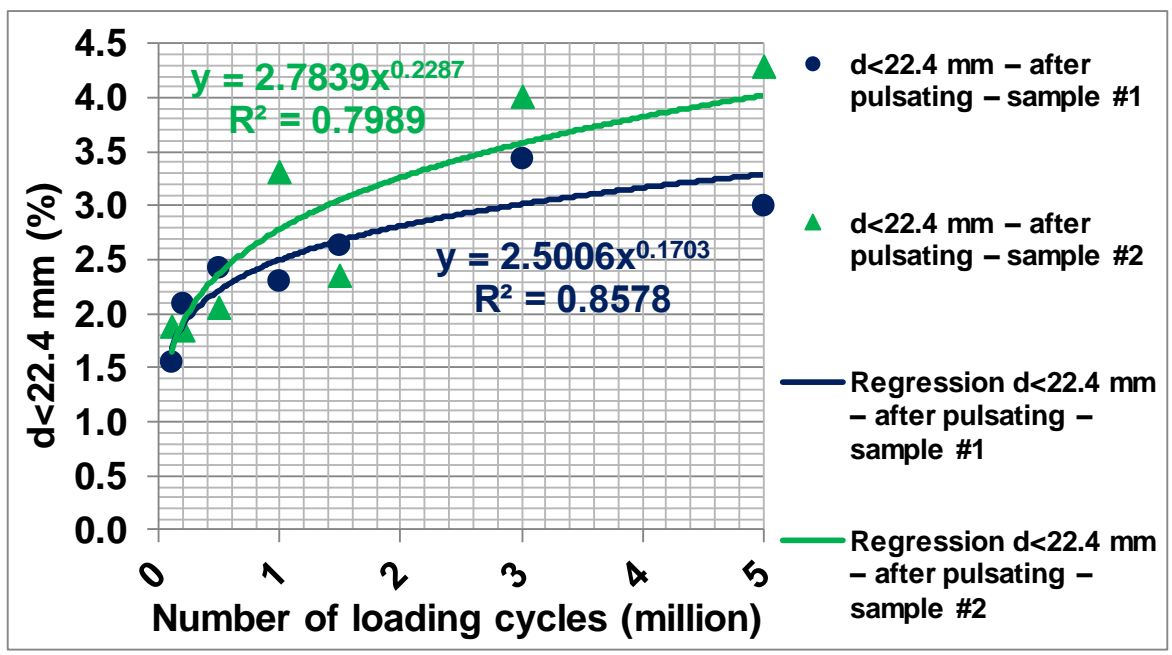

Figure 12. Results of the individual laboratory test $-d<22.4 \mathrm{~mm}(\%)$ as a function of number of loading cycles; with power regression functions 


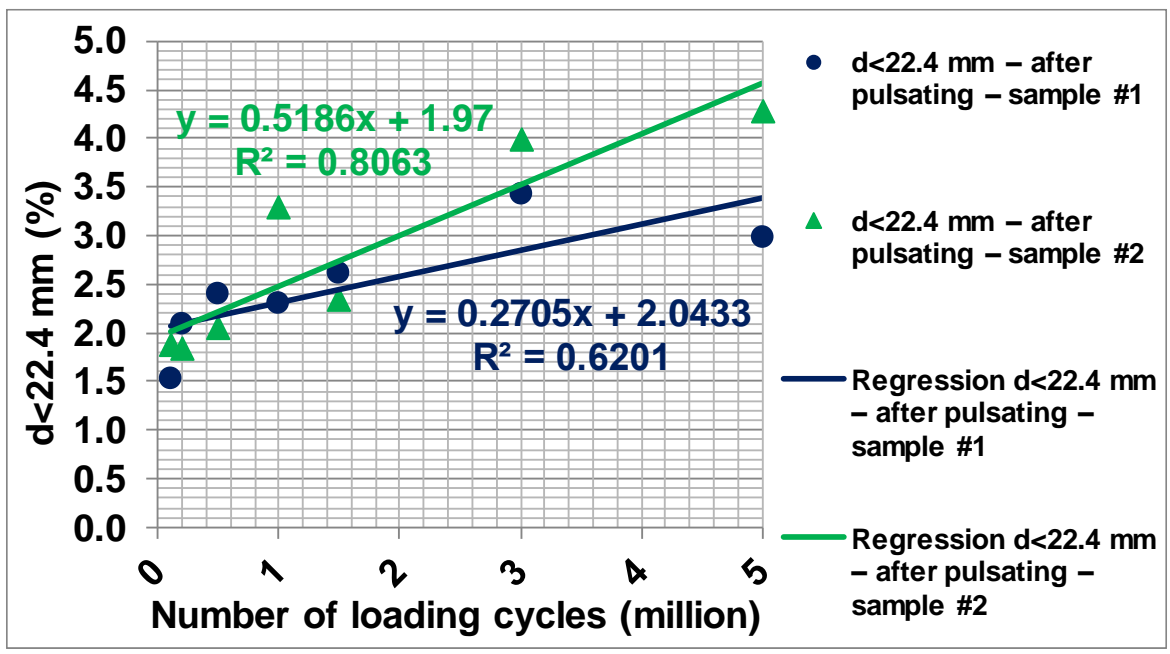

Figure 13. Results of the individual laboratory test $-d<22.4 \mathrm{~mm}(\%)$ as a function of number of loading cycles; with linear regression functions

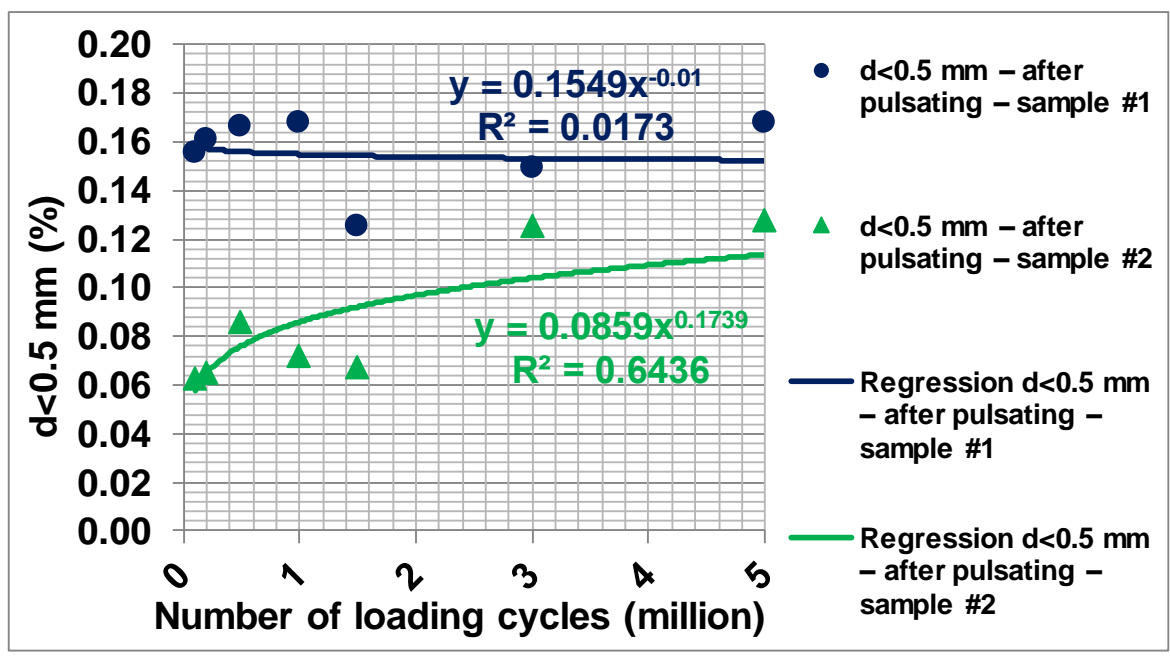

Figure 14. Results of the individual laboratory test $-d<0.5 \mathrm{~mm}(\%)$ as a function of number of loading cycles; with power regression functions 


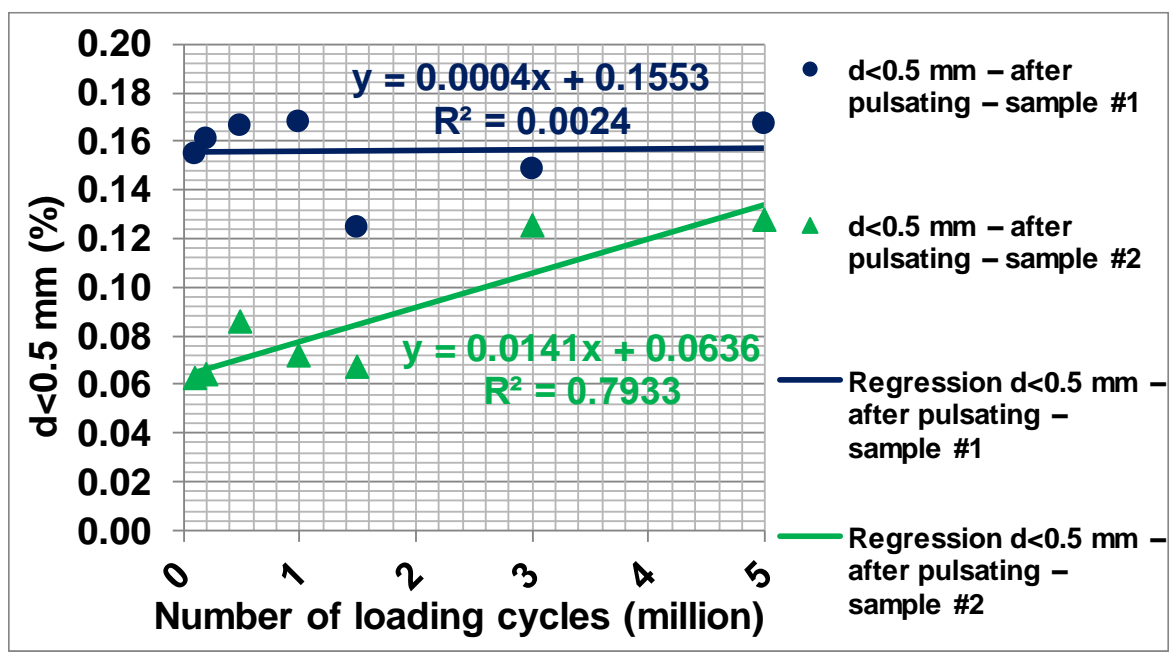

Figure 15. Results of the individual laboratory test $-d<0.5 \mathrm{~mm}(\%)$ as a function of number of loading cycles; with linear regression functions

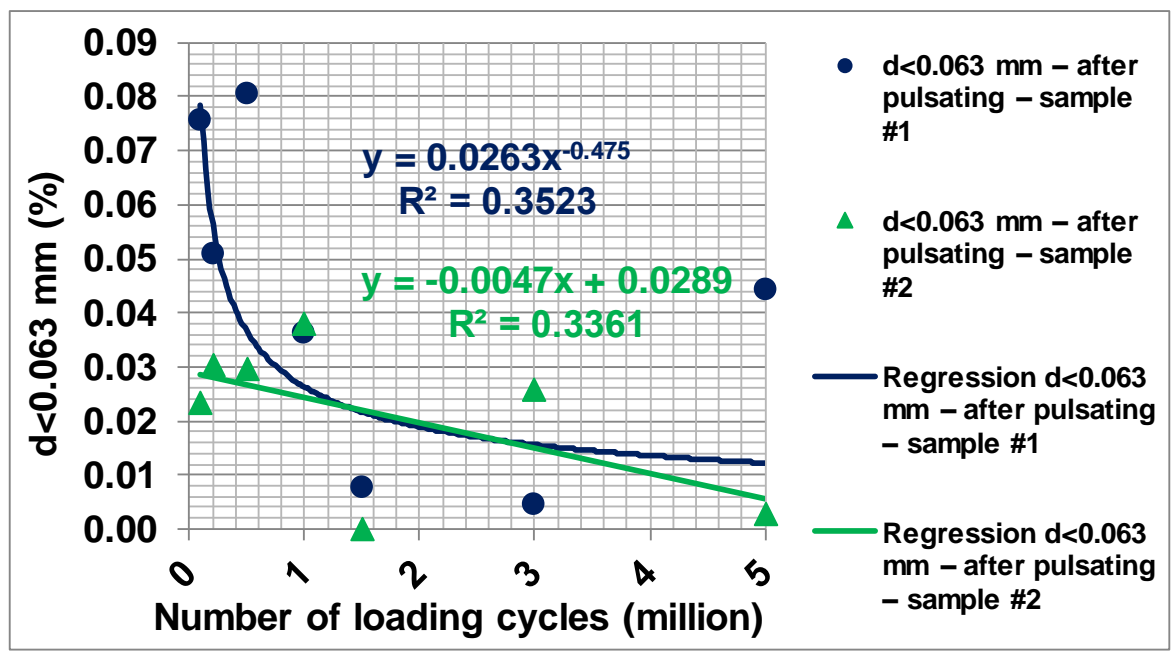

Figure 16. Results of the individual laboratory test $-d<0.063 \mathrm{~mm}(\%)$ as a function of number of loading cycles; with power and linear regression functions 


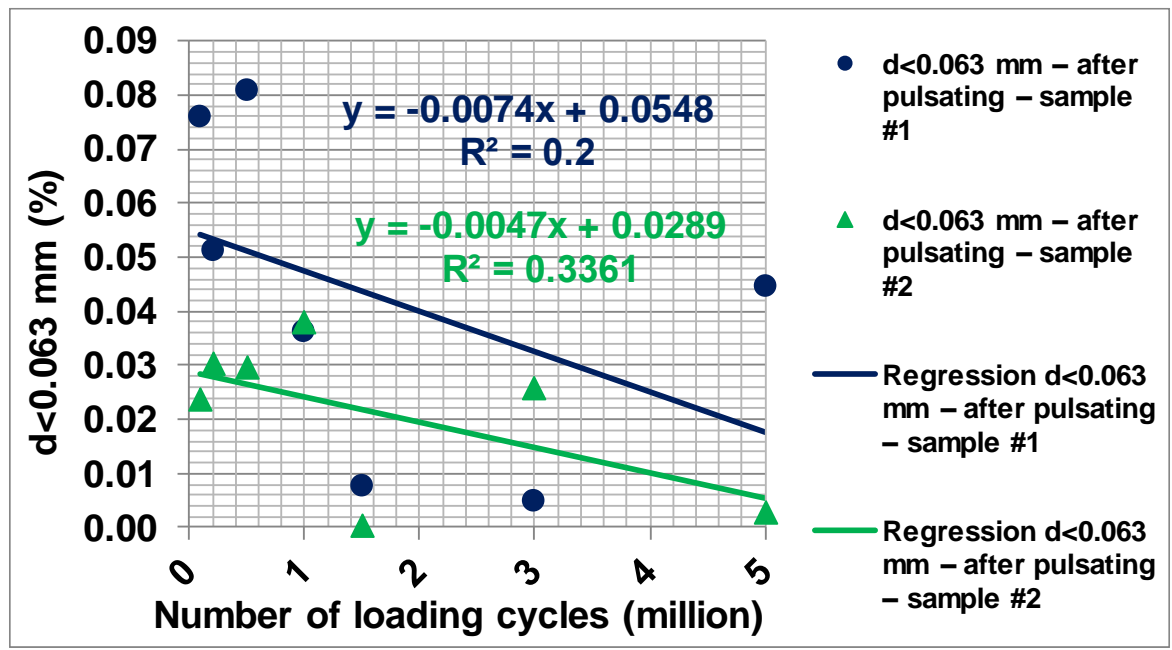

Figure 17. Results of the individual laboratory test $-d<0.063 \mathrm{~mm}(\%)$ as a function of number of loading cycles; with linear regression functions

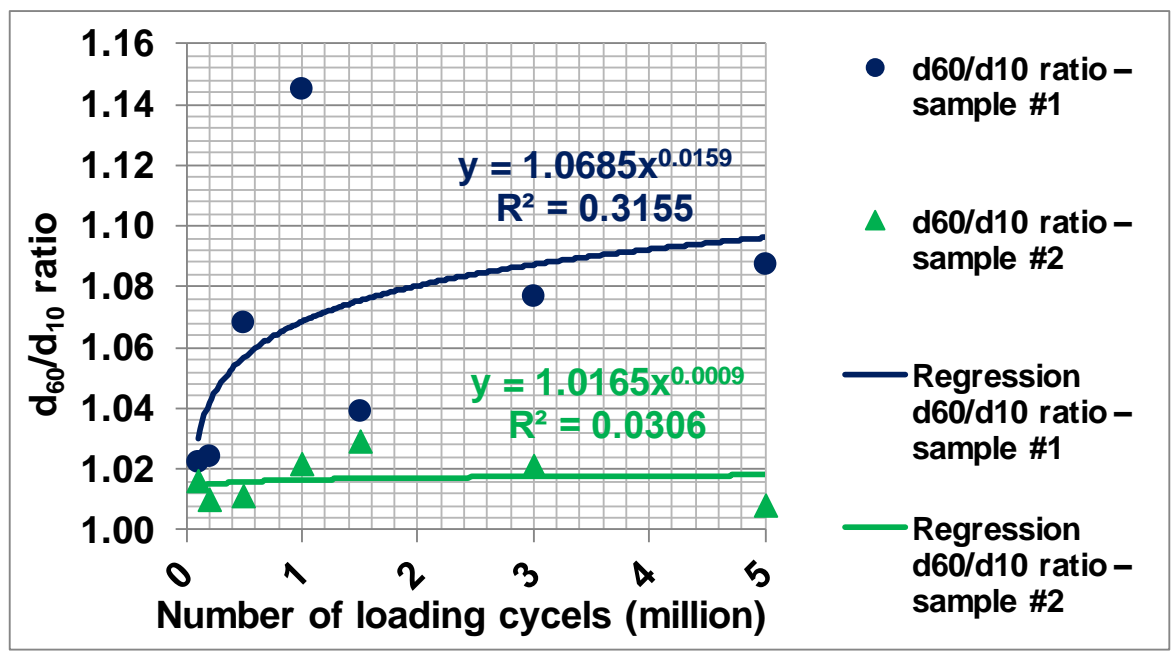

Figure 18. Results of the individual laboratory test - $d_{60} / d_{10}$ ratio as a function of number of loading cycles; with power regression functions 


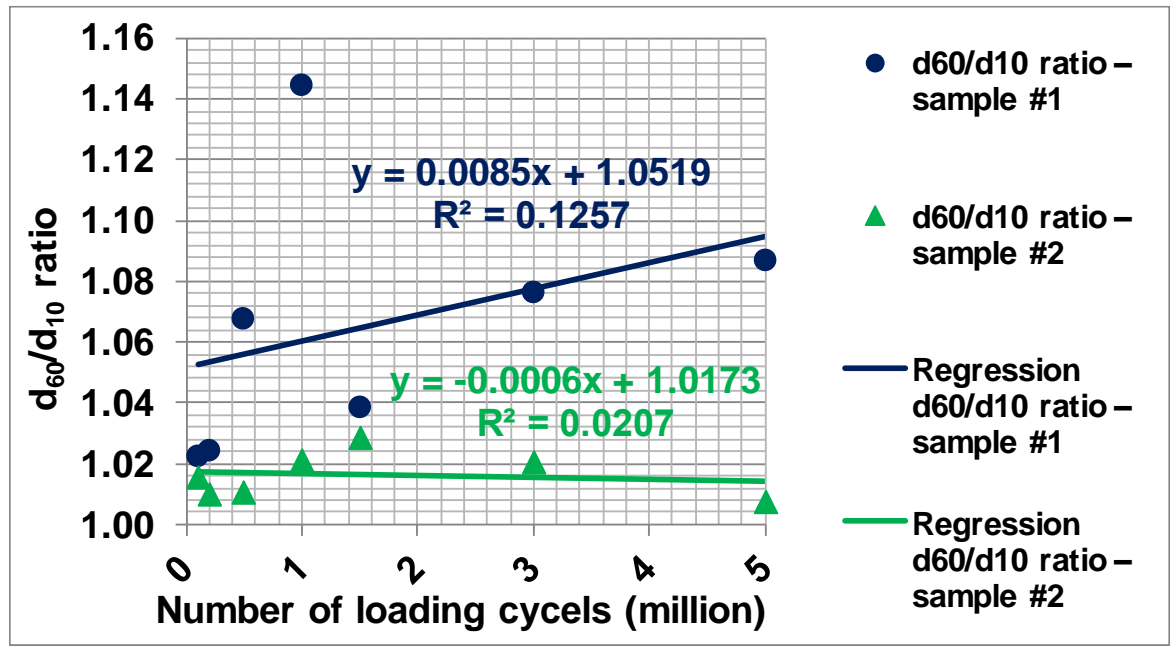

Figure 19. Results of the individual laboratory test $-d_{60} / d_{10}$ ratio as a function of number of loading cycles; with linear regression functions

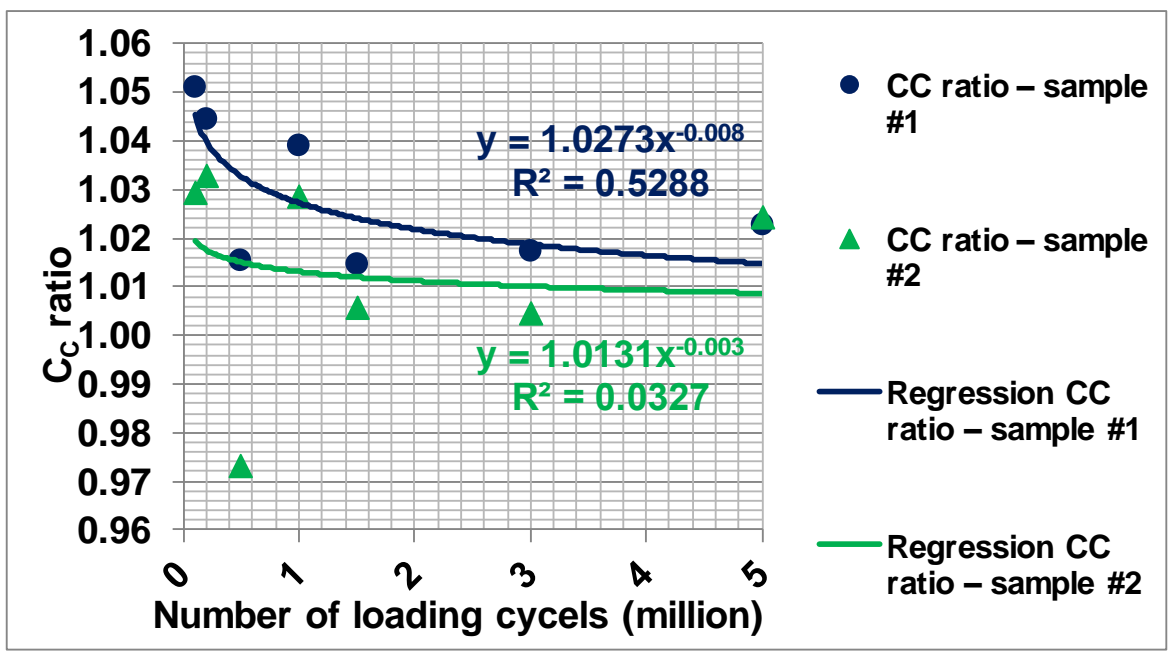

Figure 20. Results of the individual laboratory test $-C_{C}$ ratio as a function of number of loading cycles; with power regression functions 


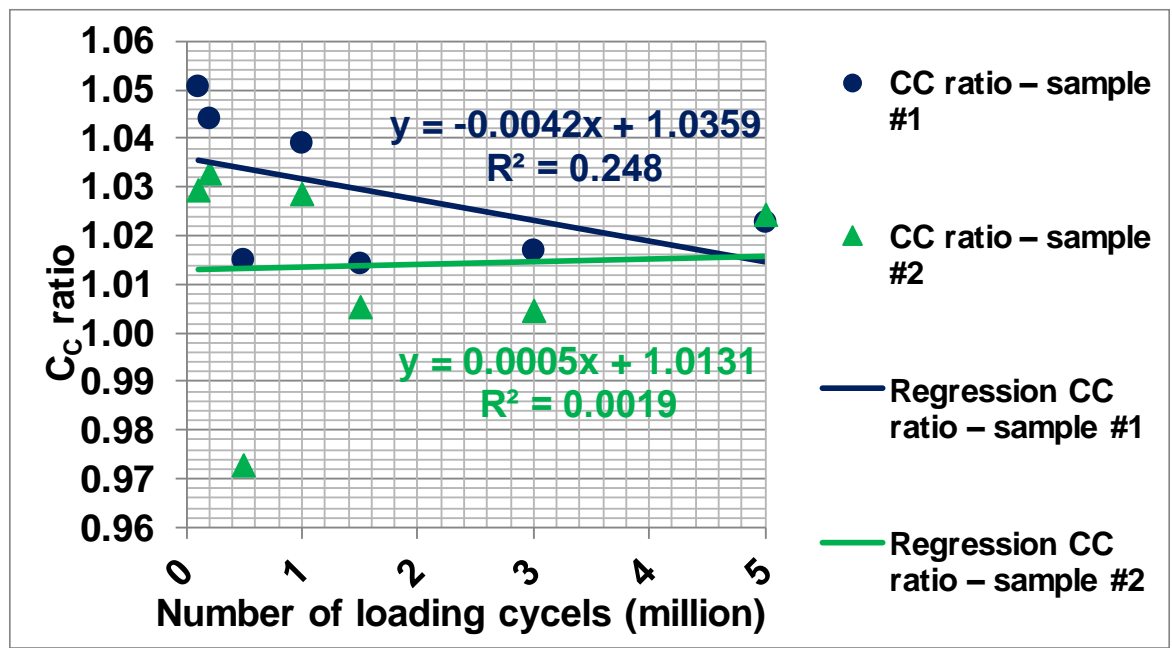

Figure 21. Results of the individual laboratory test $-C_{C}$ ratio as a function of number of loading cycles; with linear regression functions

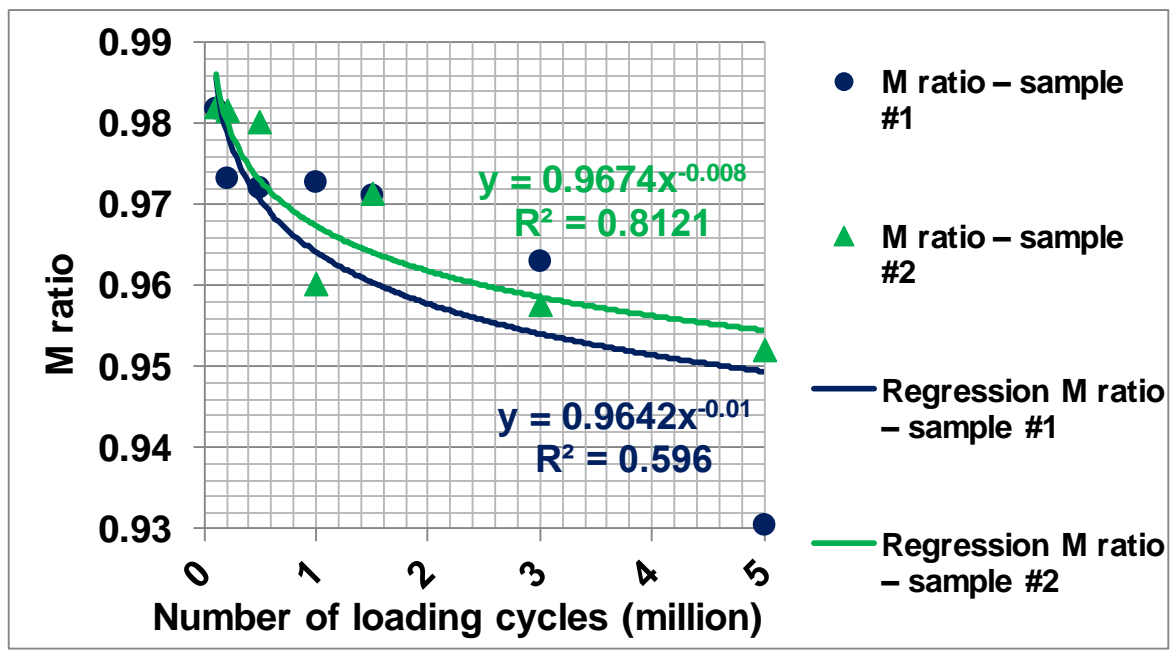

Figure 22. Results of the individual laboratory test $-M$ ratio as a function of number of loading cycles; with power regression functions 
E. Juhász and Sz. Fischer. - Acta Technica Jaurinensis, Vol. 12, No. 1, pp. 26-54, 2019

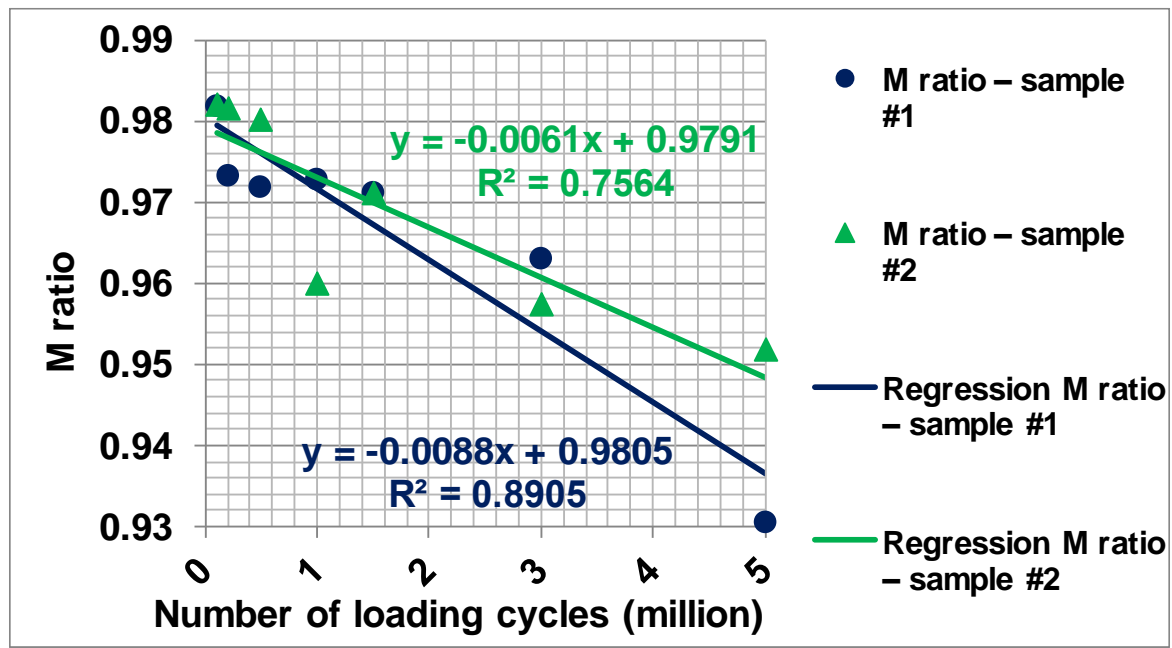

Figure 23. Results of the individual laboratory test $-M$ ratio as a function of number of loading cycles; with linear regression functions

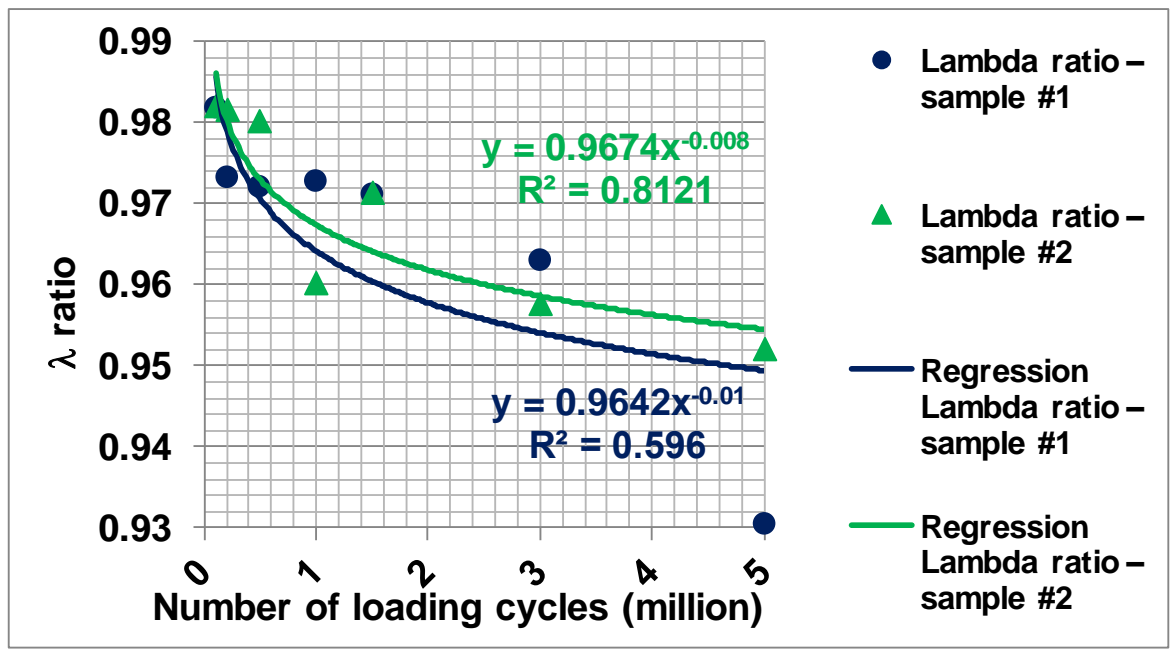

Figure 24. Results of the individual laboratory test $-\lambda$ ratio as a function of number of loading cycles; with power regression functions 


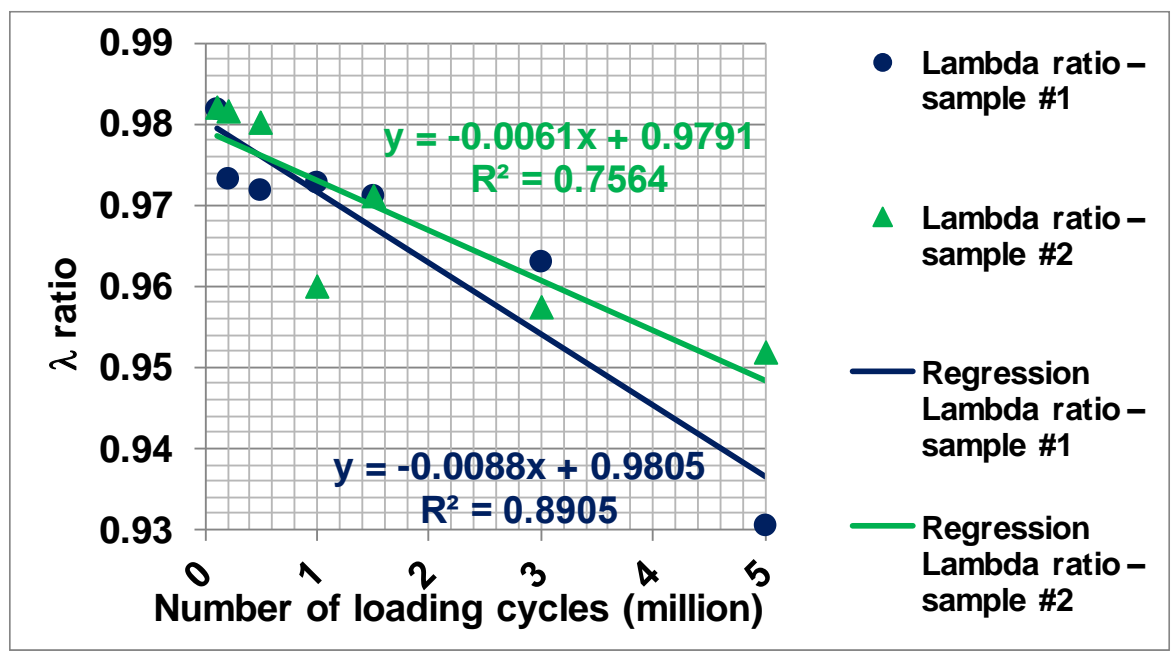

Figure 25. Results of the individual laboratory test $-\lambda$ ratio as a function of number of loading cycles; with linear regression functions

There are significant correlations in four calculated parameters from ten cases (linear and power regression functions, independent variable are the number of loading cycles):

$F_{V}$ : the parameter recommended by the South African Railways [26]. This indicates the necessity of ballast screening. It can be approximated by power regression function of the number of loading cycles (see Figure 6 ). When it reaches the 5 million loading cycles, the $F_{V}$ equals are 5.0 and $6.5 \%$. It is an interesting fact that better ballast sample deteriorates faster than the less good ballast sample. This means the considering stone physics attribution sample \#2 has lower $L A_{R B}$ and $M_{D E} R B$ values then sample \#1. Ballast screening has to be executed if $F_{V}=80 \%$ according to literature [26]. In case power regression functions are considered and number of loading cycles is calculated related to $F_{V}=80 \%$, they are $2.1 \times 10^{16}$ cycles and $2.24 \times 10^{11}$ cycles (for sample \#1 and sample \#2, respectively). These values means 8-10 million loading cycles (throughrolled axles) what are unrealistic high. On Kelenföld-Hegyeshalom state border, No. 1 railway mainline in Hungary the loading is approximately 15 million MGT/year, that is 666.667 axles/year - and it taking into consideration the common used time interval of ballast screening (12-15 
years) [26]. In this aspect, results obtained from analysis of $F_{V}$ parameter and its extrapolation cannot be used dependably.

- $\quad B B I$ : the parameter introduced by Indaratna and Lackenby $[14,15]$ to be able to calculate and assess the changing of PSD of tested samples and their quality. For calculation the BBI index, the authors have to determine the BP and AP values and with these the PSD curves. There is linear regression correlation between $\mathrm{BBI}$ and number of loading cycles (see Figure 9), but it has to be mentioned that in case of sample \#1 the R2 coefficient is negative. The negative value mathematical means that the given correlation is worse than the $y$ has constant function. It has to be mentioned that $\operatorname{BBI}(0)=0$ was a border condition. If measured data before 1.0 million loading cycle are analysed they are outliers from the defined linear trend. The measurements are needed to repeat, because of the ability to evaluate fair. BBI values are approximately $0.15 \%$ and $0.20 \%$ at 5 million loading cycles related to tested ballast material samples. It is interesting too that sample \#2 has higher tangent (steeper slope) than sample \#1 (see $F_{V}$, too). The authors neglect the negative $R_{2}$ value, because after 1.5 million loading cycles the given linear trend can be assumed). According to the literature $[14,15]$, if the $\mathrm{BBI}=1.0$, ballast screening is needed. In case number of loading cycles related to both samples are computed in the accordance $\mathrm{BBI}=1.0$, the results are 31.45 and 25.84 million cycles (for sample \#1 and \#2, respectively). That means approximately 47-year and 39-year time intervals.

- $\quad B_{R}$ : this is a similar parameter with the BBI parameter, because reference area is calculated like in case of BBI [24]. In this way the linear regression functions and correlation are very close to BBI's results. There is no technical recommendation for ballast screening related to $\mathrm{B}_{\mathrm{R}}$ (see Figures 10-11).

- $\quad d<22,4 \mathrm{~mm}$ is mass percentage: between the $d$ parameter and the number of loading cycles there are power regression relationships (see Figures 12-13). This parameter's values are approximately $3.0 \%$ and $4.25 \%$, if the number of loading cycles is $5 \times 10^{6}$ related to investigate andesite materials. This is mentioned above, but it is a surprising fact again that the sample \#2 with better properties has quicker deterioration than sample $\# 1$. According to literature [26] ballast screening has to be done if $d<22.4$ $\mathrm{mm}$ is equal or higher than $30 \%$. In case numbers of loading cycles has to be determined they are the following: $2.17 \times 10^{12}$ and $3.27 \times 10^{10}$ cycles (for sample \#1 and \#2, respectively) that are unrealistic values.

- $\quad d<0,5 \mathrm{~mm}$ is mass percentage: between the $d$ parameter and the number of loading cycles there is no power and linear regression relationship (see Figures 14-15). 
- $\quad d<0.063 \mathrm{~mm}$ is mass percentage: between the $d$ parameter and the number of loading cycles there is no power and linear regression relationship (see Figures 16-17).

- $\quad d_{60} / d_{10}$ ratio parameter: between the $d_{60} / d_{10}$ ratio parameter and the number of loading cycles there is no power and linear regression relationship (see Figures 18-19).

- $\quad C_{C}$ ratio parameter: between the $C_{C}$ ratio parameter and the number of loading cycles there is no power and linear regression relationship (see Figures 20-21).

- $\quad M$ and $\lambda$ ratio parameters: these parameters can be specified by linear regression function (see Figures 22-25). The tangent of regression function is higher in case of sample \#2 than sample \#1 (the sign is positive for sample \#2 and negative for sample \#1). The authors analysed the data more detailed and determined that there is an outlier point in case of sample \#2 (at 5 million cycles, both $M$ and $\lambda$ ratio parameters), the reason of it has to be searched by additional tests.

\section{Summary, outlook, future scope}

There are significant correlations in case of just four from the nine calculates parameters if the independent variable is the number of loading cycles (linear or power). With the other five parameters we did not achieve any results.

The authors considered the following derelictions related to calculation of time intervals between ballast screenings:

- in the whole ballast cross section comparable amount of breakage is not formulated as the one that was measured in referred laboratory tests (e.g. there is hardly no breakage in the ballast shoulder, etc.);

- machine-made and/or manual tamping occurred breakage;

- only $225 \mathrm{kN}$ axle load was taken into consideration (it is true for freight trains, for passenger trains about $180 \mathrm{kN}$ value would be more realistic);

- other ballast polluting effects (e.g. dust, concrete sleeper abrasion, breakage, in case of water pockets the increase of fine particle content in the ballast bed because of evolving pumping effect due to repeated dynamic load, etc.);

- deterioration effect accelerated by substructure or superstructure defect;

- effects of other dynamic loadings (e.g. welts, rail joints, turnout frogs [27, $28,29,30,31,32])$;

- effects of track geometry and its degradation [33].

This paper introduced the research problem related to railway ballast particle degradation. The publication sentenced that the individual laboratory testing method can be suitable for measure and evaluate ballast materials' breakage using dynamic 
pulsator. This procedure can give opportunity that ballast samples are tested in more realistic circumstances than during standardized abrasion tests.

The authors summarized the up-to-date results of exhausting international literature in this research topic; they made a remarkable successes related to ballast particle breakage.

It can be stated that better ballast material (in the aspect of stone physics) does not deteriorate slower than the worse one. Parameters that are used internationally were calculated, as well as the deterioration process was approximated linear or power regression functions related to all parameters.

The authors defined the time interval values of ballast screening based on technical prescriptions, standards and handbooks. This calculation could be done for $F_{V}, B B I$ and $d<22.4$ parameters. Only $B B I$ gave nearly acceptable results, in case of the other parameters the results are not realistic, they can't be accepted.

In some cases, additional control measurements have to be accomplished in the laboratory to be able to assess the measured data.

The authors would like to search the correlation (relationship) - as future scope between standardized parameters (Los Angeles and Micro-Deval abrasions), the prognosticated time interval between ballast screening, as well as the results from their laboratory tests. In the beginning of 2019 a modified layer structure will be considered because the extruded polystyrol sheets were significantly deformed during the dynamic tests. A stiffer and harder layer (e.g. granular protection layer or steel/concrete plate, maybe) can be modified laboratory tests' results in better way, as well as difference between substructure circumstances with XPS sheets and stiffer layer is able to be published.

The time requirement of newly developed testing method is significantly high, in this way the authors would like to execute laboratory tests with lower time demand (e.g. particle splitting tests), so relevant statements can be sentenced sooner. The authors would like to combine this splitting test with a full-field 3D shape measurement (ATOS fringe projection system) and/or X-ray measurement technique. The measurement method need to be work out $[18,34,35,36,37,38,39$, 40, 41, 42].

Beside them field tests are planned in the Hungarian railway lines. The authors would like to collect samples from old railway lines where ballast aggregates have known PSD at time of construction. The actual PSD can be definable and the changing can be determined, too. In case a lot of these kinds of measurements are able to be performed the comparison (not only field samples but the others from laboratory dynamic pulsating tests) can supply valuable results.

In the laboratory measured particle breakage values are much higher than the values in real circumstances in tracks, either in tracks with maintenance (ballast screening) demand. The reason is the only one type of loading form used in laboratory. The authors would like to develop their methodology to be able to assess 
the particle degradation more realistic. Tamping machines also break ballast particles, so this kind of effect is needed to be considered in the future research. Other additional dynamic loading effect can't be neglected in sophisticated methods, e.g. surroundings of rail welts, rail joints, as well as switch frogs where higher ballast breakage should be expected [27, 28, 29, 30, 31, 32]. Rubber coated and bitumen stabilised ballast particles hinder the geometric deterioration of railway track and ballast breakage [43, 44, 45], in detailed analysis it can be considered.

DEM simulations with particle flow code software (e.g. Itasca $\mathrm{PFC}^{3 \mathrm{D}}$ ) can be useful in the future researches to be able to evaluate particle degradation. With this DEM method the expensive laboratory tests can be saved (if the model is validated with laboratory measurements), influence effect of lots of parameters can be considered, e.g. particle shape, PSD, stone physics, abraded particles, geosynthetic reinforcements, depth of ballast, etc. This method unfortunately very lengthy, and there is just a little chance for good results.

The authors' future aim is to utilize of the results and maybe to adopt these results of the research into national regulations, standards.

This article is the direct continuation of papers [46, 47] that are accepted manuscripts without publishing yet.

\section{Acknowledgements}

The publishing of this paper was supported by EFOP 3.6.1-16-2016-00017 project.

\section{References}

[1] Sz. Fischer, Crumbling examination of railway crushed stones by individual laboratory method, Sínek Világa, 57 (3) (2015) pp. 12-19, in Hungarian.

[2] Sz. Fischer, Breakage test of railway ballast materials with new laboratory method, Periodica Polytechnica Civil Engineering 61 (4) (2017) pp. 794-802. https://doi.org/10.3311/PPci.8549

[3] Sz. Fischer, A. Németh, D. Harrach, E. Juhász, Laboratory fatigue degradation tests of railway ballast materials, in: G. Köllö (Ed.), XXII. Conference on Civil Engineering and Architecture, Sumuleu Ciuc, 2018, pp. 58-61, in Hungarian.

[4] Sz. Fischer, A. Németh, Individual rock physics investigations of railway ballast materials, in: XI. Stone and Gravel Quarry Days, Velence, 2018, pp. $37-41$, in Hungarian. 
[5] Sz. Fischer, A. Németh, Special laboratory test for evaluation breakage (particle degradation) of railway ballast, in: Conference on Transport Sciences, Győr, 2018, pp. 87-96.

[6] E. Juhász, Sz. Fischer, Investigation of railway ballast materials' particle degradation with special laboratory test method, in: Abstract book of 14th Miklós Iványi International PhD \& DLA Symposium, Pécs, 2018, pp. 89-90.

[7] Tests for mechanical and physical properties of aggregates. Part 1: Determination of the resistance to wear (micro-Deval), MSZ EN 1097-1:2012 (2012) in Hungarian.

[8] Tests for mechanical and physical properties of aggregates. Part 2: Methods for the determination of resistance to fragmentation, MSZ EN 1097-2:2010 (2010) in Hungarian.

[9] Aggregates for railway ballast, MSZ EN 13450:2003 (2003) in Hungarian.

[10] MÁV: Modification 4 in MÁV 102345/1995 Railway substructure and ballast quality acceptance regulations instruction (2010) pp. 1-5, in Hungarian.

[11] N. K. S. Al-Saoudi, K. H. Hassan, Behaviour of track ballast under repeated loading, Geotechnical and Geological Engineering 32 (1) (2014) pp. 167178.

[12] S. C. Douglas, Ballast quality and breakdown during tamping, in: Joint Rail Conference, Knoxville, 2013, pp. 940-955.

[13] R. S. Kamalov, G. S. Ghataora, M. P. N. Burrow, M. Wehbi, P. Musgrave, in: Migration of fine particles from subgrade soil to the overlying ballast, in: Railway Engineering Conference, Edinburgh, 2017, pp 1-9.

[14] B. Indraratna, S. Nimbalkar, D. Christie, The performance of rail track incorporating the effects of ballast breakage, confining pressure and geosynthetic reinforcement, in: E. Tutumluer E., I. Al-Qadi (Eds.) Bearing Capacity of Roads, Railways and Airfields, Taylor and Frances, London, 2009, pp. 5-24.

[15] B. Indraratna, Y. Sun, S. Nimbalkar, Laboratory assessment of the role of particle size distribution on the deformation and degradation of ballast under 
cyclic loading, Journal of Geotechnical and Geoenvironmental Engineering 142 (7) (2016) pp. 1-14.

https://doi.org/10.1061/(ASCE)GT.1943-5606.0001463

[16] A. Kolos, A. Konon, P. Chistyakov, Change of ballast strength properties during particle abrasive wear, Procedia Engineering 189 (2017) pp. 908-915. https://doi.org/10.1016/j.proeng.2017.05.141

[17] V. Kondratov, V. Solovyova, I. Stepanova, The development of a high performance material for a ballast layer of a railway track, Procedia Engineering 189 (2017) pp. 823-828. https://doi.org/10.1016/j.proeng.2017.05.128

[18] G. Liu, G. Jing, D. Ding, X. Shi, Micro-analysis of ballast angularity breakage and evolution by monotonic triaxial tests, in: X. Bian, Y. Chen, X. Ye (Eds.), Environmental Vibrations and Transportation Geodynamics, Springer, Singapore, 2018, pp. 133-144.

https://doi.org/10.1007/978-981-10-4508-0_12

[19] Y. Sun, C. Chen, S. Nimbalkar, Identification of ballast grading for rail track, Journal of Rock Mechanics and Geotechnical Engineering 9 (5) (2017) pp. 945-954.

https://doi.org/10.1016/j.jrmge.2017.04.006

[20] G. McDowell, Performance of geogrid-reinforced ballast, Ground Engineering January (2006), pp. 2-6.

URL https://www.geplus.co.uk/Journals/2014/06/20/b/q/m/GE-Jan-2006Performance-of-geogrid-reinforced-ballast-McDowell-Stickley.pdf

[21] S. Nimbalkar, B. Indraratna, Field assessment of ballasted rail-roads using geosynthetics and shock mats, Procedia Engineering 143 (2016) pp. 14851494. https://doi.org/10.1016/j.proeng.2016.06.175

[22] J. H. Xiao, D. Zhang, Y. H. Wang, Z. Luo, Cumulative deformation characteristic and shakedown limit of railway ballast under cyclic loading, in: The 10th International Conference on the Bearing Capacity of Roads, Railways and Airfields, Athens, 2017, pp. 1899-1904.

[23] Bearing capacity test on pavement structures, Plate bearing test, MSZ 25093:1989 (1989) in Hungarian. 
[24] A. Danesh, M. Palassi, A. A. Mirghasemi, Evaluating the influence of ballast degradation on its shear behaviour, International Journal of Rail Transportation 6 (3) (2018) pp. 145-162. https://doi.org/10.1080/23248378.2017.1411212

[25] M. Gálos, L. Kárpáti, D. Szekeres, Railway ballast aggregates (Part 2), Sínek Világa 54 (1) (2011) pp. 6-13, in Hungarian.

[26] B. Lichtberger, Track compendium, Eurailpress, Hamburg, 2011.

[27] D. M. Kurhan, To the solution of problems about the railways calculation for strength taking into account unequal elasticity of the subrail base, Nauka ta Progres Transportu 55 (1) (2015) pp. 90-99.

[28] D. Kurhan, Determination of load for quasi-static calculations of railway track stress-strain state, Acta Technica Jaurinensis 9 (1) (2016) pp. 83-96. https://doi.org/10.14513/actatechjaur.v9.n1.400

[29] V. V. Kovalchuk, M. P. Sysyn, J. Sobolevska, O. Nabochenko, B. Parneta, A. Pentsak, Theoretical study into efficiency of the improved longitudinal profile of frogs at railroad switches, Eastern European Journal of Enterprise Technologies 4 (1) (2018) pp. 27-36. https://doi.org/10.15587/1729-4061.2018.139502

[30] M. P. Sysyn, V. V. Kovalchuk, D. Jiang, Performance study of the inertial monitoring method for railway turnouts, International Journal of Rail Transportation 4 (2018) pp. 33-42. https://doi.org/10.1080/23248378.2018.1514282

[31] M. P. Sysyn, U. Gerber, V. Kovalchuk, O. Nabochenko, The complex phenomenological model for prediction of inhomogeneous deformations of railway ballast layer after tamping works, Archives of Transport 46 (3) (2018) pp. 91-107. https://doi.org/10.5604/01.3001.0012.6512

[32] Á. Vinkó, Monitoring and condition assessment of tramway track using inservice vehicle, Pollack Periodica 11 (3) (2016) pp. 73-82. https://doi.org/10.1556/606.2016.11.3.7 
[33] R. Nagy, Description of rail track geometry deterioration process in Hungarian rail lines No. 1 and No. 140, Pollack Periodica 12 (3) (2017) pp. 141-156. https://doi.org/10.1556/606.2017.12.3.13

[34] I. D. Qunitanilla. Multi-scale study of the degradation of railway ballast, thesis, Mechanical engineering, Communauté Université Grenoble Alpes (2018).

URL https://tel.archives-ouvertes.fr/tel-01858650

[35] Y. L. Guo, G. Q. Jing, Ballast degradation analysis by Los Angeles Abrasion test and image analysis method, in: Loizos et al. (Eds.), The 10th International Conference on the Bearing Capacity of Roads, Railways and Airfields (BCRRA 2017), Athens, 2017, pp. 1811-1815.

[36] Y. Qian, H. Boler, M. Moaveni, E. Tutumluer, Y. M. A. Hashash, J. Ghaboussi, Characterizing Ballast Degradation through Los Angeles Abrasion Test and Image Analysis, Trasportation Research Record 2448 (1) (2014) pp. 142-151. https://doi.org/10.3141/2448-17

[37] Y. Guo, V. Markine, J. Song, G. Jing, Ballast degradation: Effect of particle size and shape using Los Angeles Abrasion test and image analysis, Construction and Building Materials 169 (2018) pp. 414-424. https://doi.org/10.1016/j.conbuildmat.2018.02.170

[38] Y. Qian, E. Tutumluer, D. Mishra, H. Kazmee, Behavior of Geogrid Reinforced Ballast at Different Levels of Degradation, Ground Improvement and Geosynthetics, in: Selected Papers from the Proceedings of the 2014 GeoShanghai International Congress, 2014 GeoShanghai International Congress: Ground Improvement and Geosynthetics - Shanghai, 2014, pp. 333-342. https://doi.org/10.1061/9780784413401.033

[39] C. Ngamkhanong, S. Kaewunruen, C. Baniotopoulos, A review on modelling and monitoring of railway ballast, Structural Monitoring and Maintenance 4 (3) (2017) pp. 195-220. https://doi.org/10.12989/smm.2017.4.3.195

[40] Y. Guo, V. Markine, J. Song, G. Jing, Ballast degradation: Effect of particle size and shape using Los Angeles Abrasion test and image analysis, 
Construction and Building Materials 169 (2018) pp. 414-424.

https://doi.org/10.1016/j.conbuildmat.2018.02.170

[41] Y. Guo, V. Markine, X. Zhang, W. Qiang, G. Jing, Image analysis for morphology, rheology and degradation study of railway ballast: A review, Transportation Geotechnics 18 (2019) pp. 173-211. https://doi.org/10.1016/j.trgeo.2018.12.001

[42] E. Salvatore, G. Modoni, E. Ando, M. Albano, G. Viggiani, Determination of the critical state of granular materials with triaxial tests, Soils and Foundations 57 (5) (2017) pp. 733-744. https://doi.org/10.1016/j.sandf.2017.08.005

[43] M. Sol-Sánchez, G. D’Angelo, Review of the design and maintenance technologies used to decelerate the deterioration of ballasted railway tracks, Construction and Building Materials 157 (2017) pp. 402-415. https://doi.org/10.1016/j.conbuildmat.2017.09.007

[44] M. Giunta, S. Bressi, G. D’Angelo, Life Cycle Cost Assessment of Bitumen Stabilised Ballast: a novel maintenance strategy for railway track-bed, Construction and Building Materials 172 (2018) pp. 751-759. https://doi.org/10.1016/j.conbuildmat.2018.04.020

[45] G. D'Angelo, S. Bressi, M. Giunta, D. Lo Presti, N. Thom, Novel Performance-Based Technique for Predicting Maintenance Strategy of Bitumen Stabilised Ballast, Construction and Building Materials 161 (2018) pp. 1-8. https://doi.org/10.1016/j.conbuildmat.2017.11.115

[46] E. Juhász, Sz. Fischer, Breakage tests of railway ballast stone materials with using of laboratory dynamic pulsating, Sínek Világa 61 (1) (2019) pp. 16-21, in Hungarian.

[47] E. Juhász, Sz. Fischer, Investigation of railroad ballast particle breakage, accepted manuscript without publishing yet, Pollack Periodica 14 (2019). 